удк 343.337 .5

DOI 10.17150/1996-7756.2016.10(3).511-520

\title{
ОСНОВНЫЕ НАПРАВЛЕНИЯ СОВЕРШЕНСТВОВАНИЯ НОРМЫ ОБ УГОЛОВНОЙ ОТВЕТСТВЕННОСТИ ЗА ГЕНОЦИД В УК РФ
}

\author{
А.Н. Тарбагаев, Г.Л. Москалев \\ Сибирский федеральный университет, г. Красноярск, Российская Федерация
}

\author{
Информация о статье \\ Дата поступления \\ 23 ноября 2015 г. \\ Дата принятия в печать \\ 22 июня 2016 г. \\ Дата онлайн-размещения \\ 30 сентября 2016 г.

\section{Ключевые слова} \\ Геноцид; статья 357 УК РФ; \\ охраняемые группы; культурная \\ идентичность; культурный геноцид; \\ экстремизм

\section{Финансирование} \\ Исследование выполнено при \\ финансовой поддержке Российского \\ гуманитарного научного фонда \\ и Красноярского краевого фонда \\ поддержки научной \\ и научно-технической деятельности \\ в рамках исследовательского \\ проекта «Комментарий уголовного \\ законодательства о противодействии \\ террористической и экстремистской \\ деятельности» № 16-13-24001/16
}

\begin{abstract}
Аннотация. В статье ставится вопрос об архаичности диспозиции ст. 357 УК РФ (геноцид) и необходимости ее модернизации. Авторы рассматривают два наиболее актуальных на сегодняшний день направления совершенствования нормы о геноциде: расширение перечня охраняемых групп и криминализация так называемого культурного геноцида. Примерами модернизации нормы о геноциде служат статьи уголовных кодексов ряда зарубежных стран, расширивших понятие геноцида по сравнению с данным в Конвенции ООН «О предупреждении преступления геноцида и наказании за него» 1948 г. Их анализ проводится с использованием метода юридической компаративистики (сравнительное правоведение). Обнаруженные варианты диспозиции нормы об ответственности за геноцид подвергаются критике и не рекомендуются к заимствованию. Исследование исторических примеров уничтожения социальных общностей, а также основанных на них доктринальных разработок позволяет сформулировать наиболее целесообразные варианты модернизации нормы об ответственности за геноцид в УК РФ. По его результатам авторами вносится предложение по законодательному совершенствованию ст. 357 УК РФ. Среди охраняемых нормой социальных общностей следует предусмотреть человеческие группы, обладающие отличительными культурными признаками. Также предлагается исключить термин «физическое» из формулировки признака «иное создание жизненных условий, рассчитанных на физическое уничтожение членов этой группы» в диспозиции данной нормы. Анализ действующей редакции ст. 357 УК РФ показал, что подобное расширение понятия геноцида не будет противоречить его сущностным признакам и послужит усилению предупредительной функции уголовного закона. Кроме того, оно согласуется с концепцией ответственности за геноцид у исследователей, непосредственно участвовавших в разработке Конвенции 1948 г. (Р. Лемкин) или изучавших данную проблему в связи с принятием этого международно-правового акта (А.Н. Трайнин).
\end{abstract}

\section{KEY DIRECTIONS FOR MODERNIZING THE NORM ON CRIMINAL LIABILITY FOR GENOCIDE IN THE CRIMINAL CODE OF THE RUSSIAN FEDERATION}

\author{
Aleksey N. Tarbagaev, Georgii L. Moskalev \\ Siberian Federal University, Krasnoyarsk, the Russian Federation
}

Article info

Received

2015 November 23

Accepted

2016 June 22

Available online

2016 September 30

\section{Keywords}

Genocide; Art. 357 of the Criminal Code of the Russian Federation; protected groups; cultural identity; cultural genocide; extremism

\begin{abstract}
The paper raises the issues of the archaic character of the disposition of Art. 357 of the CC of the RF (genocide) and the necessity of its modernization. The authors research two most relevant directions for improving the norm on genocide: widening the list of protected groups and the criminalization of the so-called cultural genocide. The articles of criminal codes in some countries can serve as examples of modernizing the norm on genocide by widening the concept of genocide in comparison with the UNO Convention for the Prevention and Punishment of the Crime of Genocide adopted in 1948. They were analyzed using the method of legal comparativistics (comparative jurisprudence). The identified options of dispositions of the norm on liability for genocide are criticized and their adoption is not recommended. The research of historical examples of extermination of social communities and the doctrines based on them make it possible to formulate the most appropriate options for modernizing the norm on liability for genocide in the CC of the RF. Research results allow the authors to make a suggestion on the legislative improvement of Art. 357 of the CC of RF. Human communities characterized by specific cultural attributes should be included
\end{abstract}




\section{Financing}

This research is financially supported by the Russian Humanitarian Science Foundation and the Krasnoyarsk Region Science and Technology Support Fund within the project «A Comment to Criminal Legislation on Counteracting Terrorist and Extremist Activities» № 16-13-24001/16 in the number of social communities protected by the norm. The authors also suggest eliminating the term «physical» from the statement "other creation of living conditions aimed at the physical extermination of the members of this group» in the disposition of this norm. The analysis of the current version of Art. 357 of the CC of RF showed that such widening of the concept of genocide will not contradict its essential attributes and will strengthen the preventive function of criminal law. Besides, it agrees with the concept of liability for genocide formulated by those researchers who were immediately involved in the development of the Convention of 1948 (R. Lemkin) or studied this issue in connection with the ratification of this criminal law act (A.N. Trainin).
Норма об уголовной ответственности за геноцид в УК РФ появилась в результате исполнения Россией обязательства по приведению своего национального законодательства в соответствие с положениями Конвенции ООН «О предупреждении преступления геноцида и наказании за него» (далее - Конвенция 1948 г.), закрепленного в ст. V данного акта. Указанный договор заключал еще СССР, и введение в отечественное уголовное законодательство нормы о геноциде представляется запоздалым, но необходимым и целесообразным. Сопоставление определений геноцида в ст. 357 УК РФ и ст. II Конвенции 1948 г. демонстрирует наличие некоторых отличий, возникших в большинстве своем, как мы полагаем, в результате неточного переноса конвенционных признаков геноцида в российский уголовный закон. Однако основные признаки исследуемого преступления в этих актах сформулированы практически одинаково. Данное обстоятельство свидетельствует о намерении отечественного законодателя дать определение геноцида в максимальном соответствии с международно-правовым понятием этого преступления.

На первый взгляд, трудно упрекнуть законодателя в выборе такого подхода. Однако не стоит забывать о том, что к моменту принятия действующего УК РФ конвенционное понятие геноцида существовало уже 48 лет и ни разу не подвергалось изменениям. При этом посягательства на объект, охраняемый нормами о геноциде, в мире совершались регулярно, обрастая различными дополнительными признаками, требующими внимания законодателя и правоприменителя. Конвенция 1948 г. не была рассчитана на то, чтобы отвечать новым вызовам в сфере совершения общественно опасных деяний против безопасности человечества. Таким потенциалом обладают нормы о геноциде в национальных уголовных законах. К содержанию последних и стоит обратиться за примерами иных подходов к определению более современного понятия геноцида. Законодательное совершенствование норм о геноциде в национальных уголовных за- конах, и в частности в УК РФ, выступает важной предпосылкой предупреждения этого преступления и обеспечения полноценной охраны демографических общностей, указанных в диспозициях соответствующих статей (в России, например, в ст. 357 УК РФ).

Наибольший исследовательский интерес представляют уголовные кодексы зарубежных стран, в которых норма о геноциде по содержанию отличается от нормы Конвенции 1948 г. [1]. Совершенствование нормы заключается в расширении круга деяний, охватываемых понятием геноцида, по сравнению с Конвенцией 1948 г., поскольку его сужение может рассматриваться как неисполнение государством своих обязательств по борьбе с геноцидом, закрепленных в ст. I, V Конвенции 1948 г. С точки зрения исследования данная группа уголовных кодексов зарубежных стран представляет наибольший интерес. Именно в таких актах содержатся примеры модернизации нормы об ответственности за геноцид, учитывающие факты совершения этого преступления, имевшие место после принятия Конвенции 1948 г. Варианты, избираемые для совершенствования норм о геноциде в разных странах, различаются. Критически анализируя их, потенциально можно обнаружить наиболее удачные и перспективные, которые способны стать основой для модернизации нормы о геноциде в российском УК.

Одним из наиболее обсуждаемых направлений совершенствования норм об уголовной ответственности за геноцид является увеличение количества охраняемых этими нормами групп. Сторонники такой модернизации опираются на события в истории человечества, в рамках которых происходило уничтожение групп, помимо тех, безопасность которых охраняется как Конвенцией 1948 г., так и ст. 357 УК РФ. А подобные факты действительно имели место.

Уничтожение групп, не указанных в диспозиции нормы о геноциде, осуществлялось режимом красных кхмеров в Камбодже в 1975-1979 гг. В рамках борьбы с пережитками прошлого ис- 
треблению подвергались не только национальные меньшинства и религиозные общины, но и представители интеллигенции, торговцы, чиновники, бывшие чиновники, офицеры и сторонники прежнего правительства [2, с. 34]. Как видно, подлежащие уничтожению лица выбирались не только по национальному и религиозному признакам, но и по признакам социального положения, идеологических взглядов. И, хотя национальность жертв в подавляющем большинстве случаев не имела определяющего значения, данное деяние было квалифицировано как геноцид по нормам указа от 15 июня 1979 г. Народно-революционного совета Камбоджи [2, с. 34]. Народно-революционный трибунал посчитал, что действия, совершенные красными кхмерами, были такими тяжкими, что по этому критерию не имели аналогов в мировой истории. Поэтому он расширил перечень групп в норме о геноциде по сравнению с их перечнем в Конвенции 1948 г.

Невозможно однозначно говорить об уничтожении групп, входящих в диспозицию международно-правовой нормы о геноциде, в рамках признанных геноцидом событий в Руанде 1994 г. Во многом именно деятельность Международного трибунала по Руанде обусловила современную дискуссию среди зарубежных исследователей о группах, охраняемых международной нормой о геноциде [3]. Дело в том, что на протяжении большей части истории разделение населения этой страны на хуту и тутси основывалось на признаке принадлежности к власти, аристократии. Существовала возможность индивидуального перехода из одной группы в другую [4, р. 103]. Профессор социологии и экономики Лилльского университета Андре Гуичаоа отмечал, что все группы в Руанде разделяли одну национальную территорию, разговаривали на одном языке, верили в одни мифы и соблюдали одни обычаи [5], что не может говорить об этническом разделении хуту и тутси. В совокупности с наличием многочисленных фактов смешанных браков между представителями этих групп на протяжении многих поколений приходится констатировать отсутствие вообще каких-либо биологических или культурных различий между ними [6, с. 25].

В пользу определения данных групп как этнических говорило введение в середине XX в. специальных карточек, в которых индивидуальная принадлежность лица к одной из них обозначалась именно этнической, а переход в другую группу не предполагался. В результате Международным трибуналом по Руанде хуту и тутси были признаны все же этническими группами [7], что нашло отражение в решениях этого международного суда по ряду дел ${ }^{1}$. Однако с учетом имевших место споров была вероятность поддержки другой позиции, которая привела бы к невозможности квалифицировать истребление около 800 тыс. представителей тутси как геноцид.

События 1982-1983 гг. в Гватемале также содержали уничтожение групп, не охватываемых нормой о геноциде Конвенции 1948 г. Помимо индейцев этой страны, истреблению подвергались члены профсоюзов, политическая оппозиция, группы лиц, оказывавших поддержку мятежникам². Таким образом, одновременно уничтожались группы как этнические, так и определяемые на основе идеологической ориентации.

К сожалению, примеры умышленного уничтожения человеческих групп, выделяемых по иным, не предусмотренным Конвенцией 1948 г. признакам, содержит и отечественная история. Так, в ходе насильственной коллективизации сельского хозяйства, проведенной в СССР в 19201930-х гг., одним из направлений государственной политики стала «ликвидация кулачества как класса» - раскулачивание, предполагавшее насильственное лишение зажиточных крестьян всех средств производства, земли и гражданских прав и выселение их в отдаленные районы страны, а также лишение свободы с пребыванием в лагерях [8, с. 36]. Было названо кулаками и подвергнуто репрессиям от 5 до 15 млн крестьян $[9$, с. 34]. Нетрудно увидеть, как в результате действий, указанных в нормах о геноциде, в конечном счете уничтожались лица, выделяемые по признакам экономической принадлежности к социальной группе и, соответственно, нормой
${ }^{1}$ Cм., напр.: International Tribunal for the Rwanda. Judgment Prosecutor v. Jean-Paul Akayesu (Case No. ICTR- 96-4-T) of 02.11.1998 [Electronic resource] // UNICTR. ORG : офиц. сайт Междунар. трибунала по Руанде. URL : http://www.unictr.org/Portals/0/Case/English/Akayesu/ judgement/akay001.pdf ; International Tribunal for the Rwanda. Judgment Prosecutor v. George Rutaganda (Case No. ICTR-96-3-T) of 07.06.2001 [Electronic resource]. URL : http://www.unictr.org/sites/unictr.org/files/case-docu- ments/ictr-96-3/trial-judgements/en/991206.pdf ; Inter- national Tribunal for the Rwanda. Judgment Prosecutor v. Clement Kayishema and Obed Ruzindana (Case No. ICTR- 95-1-T) of 21.05.1999 [Electronic resource]. URL : http:// www.unictr.org/Portals/0/Case/English/kayishema/judge- ment/990521_judgement.pdf ; и др.
2 Бывший гватемальский диктатор приговорен к 80 годам тюрьмы за геноцид [Электронный ресурс] // Российская газета. 2013. 11 мая. URL : http://www. rg.ru/2013/05/11/genocid-anons.html. 
об ответственности за данное преступление не предусмотренные.

Норма о геноциде в российском УК не учитывает указанные события и повторяет перечень групп за Конвенцией 1948 г. Данное обстоятельство ставит вопрос о необходимости модернизации ст. 357 УК РФ путем расширения круга человеческих групп, охраняемых нормой. С другой стороны, изложенные исторические факты не остались незамеченными некоторыми зарубежными законодателями и обусловили появление в нормах о геноциде в национальных законодательствах многих стран групп, не упомянутых в Конвенции 1948 г. Таким образом, существуют образцы проведения такой модернизации.

В качестве примера можно привести ч. 1 ст. 118 УК Польши 1997 г., в которую, помимо национальной, этнической, расовой и религиозной группы, включены политические группы и группы с определенным мировоззрением ${ }^{3}$. Также за счет политических групп расширена норма о геноциде в ст. 269 Ук Эфиопии ${ }^{4}$. Политические группы и группы лиц, определенные наличием общих убеждений, упоминаются соответственно в ст. 99 УК Литвы ${ }^{5}$ и в ст. 71 УК Латвии ${ }^{6}$ Очевидно, что для охраны безопасности групп, выделяемых по признаку политических убеждений, упоминается в ст. 90 УК Эстонии группа, оказывающая сопротивление оккупационному режиму7.

Однако в соответствующих статьях о преступлении геноцида уголовных кодексов стран Балтии указанные группы охватываются более широким признаком. Они подпадают под понятие «любой социальной группы», также перечисленного в данных нормах. Не менее радикально перечень групп, в отношении которых может совершаться геноцид, расширен в ст. 127 УК Республики Беларусь. Предусматривая ответствен-

${ }^{3}$ Уголовный кодекс Республики Польша от 1 янв. 1997 г. (ред. от 1 авг. 2001 г.) : пер. с пол. СПб. : Юрид. центр Пресс, 2001. 234 с.

${ }^{4}$ The Criminal Code of the Federal Democratic Republic of Ethiopia (Proclamation No. 414/2004) [Electronic resource] // ILO.ORG : офиц. сайт Междунар. организации труда. URL : http://ilo.org/dyn/natlex/docs/electronic/70993/75092/f1429731028/eth70993.pdf.

5 Уголовный кодекс Литовской Республики от 26 сент. 2000 г. (ред. от 12 февр. 2007 г.) : пер. с лит. СПб. : Юрид. центр Пресс, 2003. 468 с.

6 Уголовный кодекс Латвийской Республики от 1 апр. 1999 г. (ред. от 1 авг. 2001 г.) : пер. с лат. СПб. : Юрид. центр Пресс, 2001. 313 с.

7 Уголовный кодекс Эстонской Республики от 1 сент. 2002 г. (ред. от 6 дек. 2005 г.) : пер. с эст. СПб. : Юрид. центр Пресс, 2005. 262 с. ность за это преступление, указанная норма к национальной, этнической, расовой и религиозной группе добавляет «группы, определенные на основе любого произвольного критерия» ${ }^{8}$. За счет такой же формулировки расширена норма о геноциде в ст. 211.1 УК Франции ${ }^{9}$ и ст. 407 УК Грузии ${ }^{10}$. В сущности, так же расширялся перечень групп и в ст. 220а УК Федеративной Республики Германия ${ }^{11}$, в которой говорилось о группах, различающихся своими особенностями. Формулировки, использованные для модернизации нормы о геноциде во Франции, ФРГ, Грузии и Беларуси, с одной стороны, и прибалтийских государствах - с другой, хотя текстуально и отличаются, но расширяют перечень охраняемых групп практически одинаково. Ведь всякая социальная группа - это и есть группа, объединенная на основе любого произвольного критерия, отличающаяся от других групп своими особенностями.

Вызывает интерес расширение перечня групп, безопасность которых охраняется, в секции 1 гл. 11 УК Финляндии. Данная норма к национальной, этнической, расовой и религиозной добавила «любую другую сопоставимую группу ${ }^{12}$. При всей своей оригинальности указанная формулировка видится наименее удачной среди всех упомянутых выше. Ведь совершенно неясно, по каким признакам необходимо осуществлять сопоставление. Пожалуй, формулировка, использованная финским законодателем, может служить лишь образцом неудачной модернизации нормы о геноциде в национальном законодательстве.

Указанные примеры иллюстрируют имеющуюся в национальном праве зарубежных стран тенденцию к расширению круга групп, охраняемых нормами о геноциде. Однако в разных государствах данная модернизация различается, и вводимые в норму о геноциде группы зачастую

8 Уголовный кодекс Республики Беларусь от 9 июля 1999 г. СПб. : Юрид. центр Пресс, 2001. 474 с.

9 Уголовный кодекс Франции : принят в 1992 г., вступил в силу с 1 марта 1994 г. : с изм. и доп. на 1 янв. 2002 г. СПб. : Юрид. центр Пресс, 2002. 650 с.

${ }^{10}$ Уголовный кодекс Грузии от 22 июля 1999 г. (ред. 9 янв. 2007 г.) [Электронный ресурс] // Юридическая Россия : Федер. правовой портал. URL : http://law.edu. ru/norm/norm.asp?normID=1241370.

11 Уголовный кодекс ФРГ от 15 мая 1871 г. (ред. от 13 нояб. 1998 г.) : пер. с нем. М. : Зерцало, 2000. 202 с.

12 The Criminal Code of Finland (39/1889, amendments up to $927 / 2012$ included) [Electronic resource] // FINLEX.FI: online database of up-to-date legislative and other judicial information of Finland. URL : http://finlex.fi/ en/laki/kaannokset/1889/en18890039.pdf. 
не совпадают. Введение в нормы о геноциде политических групп, а также групп с определенным мировоззрением, очевидно, основано на многочисленных исторических примерах уничтожения таких групп. Некоторые примеры уже были приведены. Но поскольку история пестрит событиями истребления групп, выделяемых и по иным признакам, можно говорить об оправданности введения в перечень групп, в отношении которых совершается геноцид, и любых других социальных общностей. Для понимания того, какой путь модернизации можно принять как предпочтительный для российского законодателя, стоит обратиться к имеющимся на сегодняшний день доктринальным позициям по анализируемому вопросу.

В первую очередь необходимо отметить, что у идеи увеличения количества групп, охраняемых нормами о геноциде, есть и свои немногочисленные противники. Признавая исторические факты уничтожения групп, выделяемых по признакам, нехарактерным для национальной, этнической, расовой или религиозной группы, они утверждают, что эти события сами по себе не означают необходимости включения новых групп в нормы о геноциде $[5 ; 10$, с. 86]. Соглашаясь с данным тезисом, мы все же считаем рассматриваемое направление совершенствования норм о геноциде правильным. Но группы, которые должны охраняться нормой о геноциде, предлагается определять не только на основе исторического опыта, как это делают некоторые исследователи [11, с. 41], но и руководствуясь сущностью этого преступления. Однако понимают ее многие авторы по-разному. Так, Н.В. Мошенская полагает, что «геноцид означает преднамеренное преступление, нацеленное на истребление группы людей, выделяемой по своей принадлежности к какому-либо сообществу» [9, с. 35]. Давая такое определение, автор поддерживает максимальное расширение круга групп, в отношении которых может быть совершен геноцид, до любой социальной группы. Однако, как справедливо отмечают критики изложенной точки зрения, в таком случае допускается совершение геноцида в отношении вообще любой группы, существующей в обществе, в частности любителей гольфа [5], криминальных сообществ, семей и т.д. Чрезмерно широкое содержание признака «социальная группа» и, как следствие, неудачность его использования в уголовном законе были отмечены исследователями применительно к формулировке экстремистского мотива [12; 13]. В случае рас- ширения круга групп, в отношении которых может совершаться геноцид, до любых социальных общностей данная критика станет актуальной и для ст. 357 УК РФ.

В качестве критерия расширения перечня групп, охраняемых нормой о геноциде, некоторыми исследователями предлагается использовать признак добровольности участия. Так, предлагается не включать в перечень групп, указанных в диспозиции нормы о геноциде, те, принадлежность лица к которым обусловлена его добровольным волеизъявлением [6, с. 15; 14, с. 215]. Таковыми являются, например, общества по профессиональным, экономическим и другим подобного рода интересам. С указанным критерием не соглашаются в первую очередь сторонники расширения понятия геноцида за счет указания на политические группы [15, р. 26], что, как уже было отмечено, зачастую реализуется в национальных уголовных кодексах зарубежных стран и имеет историческое обоснование. С рассматриваемым критерием, на наш взгляд, нельзя согласиться прежде всего потому, что норма о геноциде охраняет безопасность религиозных групп, членство в которых основано как раз на добровольных началах. Таким образом, критерий добровольности участия противоречит изначально заложенным в норму о геноциде идеям и не может быть принят.

Другим критерием, предлагаемым в доктрине для определения групп, безопасность которых должна охраняться нормами о геноциде, является общественная значимость группы [16, с. 141]. Определить наличие данного критерия, с точки зрения исследователей, его выдвигающих, могут такие характеристики группы, как численность, устойчивость, продолжительность существования или какая-либо важная роль [16, с. 142]. Однако указанные характеристики, по нашему мнению, не могут определить значимость группы и не в состоянии отделить группы, охрана которых должна осуществляться, от иных групп. Например, история сообщества охотников-любителей насчитывает не одну сотню лет. В составе этого сообщества большое количество людей. Выбирая охоту своим хобби, они, как правило, не изменяют привычке, что свидетельствует об устойчивости сообщества. Будучи социальной группой, в рамках которой реализуются интересы людей, оно играет важную роль в жизни общества. Можно увидеть, что сообщество охотниковлюбителей отвечает критерию общественной значимости в значении, предлагаемом критикуе- 
мыми исследователями. Однако неужели подобная аргументация может привести нас к выводу о возможности совершения геноцида любителей охоты и необходимости включения безопасности данной группы в объект геноцида? Отрицательный ответ на этот вопрос очевиден.

Проанализировав группы, указанные как в Конвенции 1948 г., так и в ст. 357 УК РФ, можно обнаружить, что их объединяет не просто общественная значимость. Эти группы имеют уникальные отличительные признаки, позволяющие провести их идентификацию. Так, расовые группы обладают уникальными биологическими, генетическими характеристиками, которые дают возможность отделять одну такую группу от другой. В случае с религиозными, национальными и этническими группами следует говорить о культурной идентичности. Ведь именно по различающемуся мировоззрению можно разграничить религиозные группы. Поскольку только по различиям в культуре можно отличить этносы или нации, в науке выделяют, соответственно, этническую и национальную культуры. Уничтожение этих групп несет угрозу всему человечеству [17], так как сокращает культурное и генетическое разнообразие человеческого рода. О том, что выбор охраняемых групп при разработке Конвенции 1948 г. осуществлялся в соответствии с изложенной логикой, говорят работы основателя концепции геноцида Р. Лемкина. В своей статье 1947 г. он отмечал, что геноцид «приводит к особым потерям для цивилизации в форме культурных достижений, которые могут принадлежать исключительно определенным группам людей, объединенным национальными, расовыми или культурными признаками» [18].

Под культурой мы понимаем накопленную человечеством за весь период его существования совокупность знаний и умений, направленных на его самосохранение, воспроизводство, самосовершенствование, воплощенную в нормах жизни, в предметах материальной и духовной культуры [19, с. 456]. Используя это определение, можно увидеть, что уникальной культурной идентичностью обладают не только национальные, этнические и религиозные группы. Так, уничтожение групп, члены которых разделяют определенные политические взгляды, сокращает мировоззренческое разнообразие, в сущности, так же, как и при истреблении религиозной группы. Уникальными культурными характеристиками могут обладать сословные или кастовые группы в обществах с существенно ограниченной или закрытой социальной мобильностью. Навыки и методы работы, которых нет у других, могут иметь профессиональные группы. Наконец, в этнографических классификациях человеческих сообществ выделяют и иные, помимо национальных и этнических, группы, которым свойственны отличительные признаки, например народности, народы, субэтносы и т.д. Но безопасность всех этих групп оказывается не защищенной от геноцида ввиду закрытости перечня групп, указанных в норме об ответственности за это преступление. Данный недостаток Конвенции 1948 г. унаследовала и ст. 357 УК РФ. В отношении российской нормы существует необходимость ее законодательной модернизации путем указания в диспозиции ст. 357 УК РФ на направленность «на полное или частичное уничтожение расовой, национальной, этнической, религиозной или иной обладающей отличительными культурными признаками группы».

Другое направление совершенствования нормы о геноциде восходит к теоретической концепции этого преступления Р. Лемкина - исследователя, впервые в истории сформулировавшего понятие геноцида. Помимо физического истребления социальных групп, под геноцидом автор также понимал различные формы уничтожения их культурной идентичности. Среди таковых исследователь называл систематическое уничтожение или изъятие культурных ценностей, уничтожение книг на языке группы, запрещение употреблять родной язык, разрушение музеев, школ, исторических памятников, культовых и других учреждений, культурных объектов группы или запрещение пользоваться ими [20, р. 40; 21, р. 84]. До принятия Конвенции 1948 г. в актах Генеральной Ассамблеи ООН также отмечалась опасность геноцида для всего человечества, проявляющаяся в потере культурных ценностей, представляемых человеческими группами ${ }^{13}$. Однако ни в тексте Конвенции 1948 г., ни в принятых на ее основе национальных нормах об ответственности за геноцид не упоминается уничтожение культуры охраняемых групп в перечне альтернативных признаков объективной стороны этого преступления.

Среди исследователей существуют как сторонники, так и противники концепции культурного геноцида. Последние настаивают на

13 Преступление геноцида [Электронный ресурс] : резолюция Генер. Ассамблеи ООН от 11 дек. 1946 г. № 96 (1) // Организация Объединенных Наций : офиц. сайт. URL : http://daccess-dds-ny.un.org/doc/RESOLUTION/ GEN/NRO/035/52/IMG/NR003552.pdf?OpenElement. 
том, что действия по искоренению культуры не могут привести к уничтожению национальной, этнической, расовой или религиозной группы [5; 22]. Однако с подобной позицией нельзя согласиться. Зачастую физическая ликвидация человеческих групп сопровождалась разрушением предметов их культуры. Так, план руководства нацистской Германии по уничтожению некоторых восточноевропейских народов предполагал в том числе разрушение памятников их материальной культуры [23]. Как известно, данный план реализовывался посредством как физического истребления представителей этих народов [24; 25], так и действий, направленных на искоренение их культурно-духовной идентичности, среди которых главное место занимало уничтожение культуры [23]. Совершаемые нацистским режимом действия обладали высокой степенью взаимосвязанности, так как были направлены на уничтожение человеческих групп и могли привести к их исчезновению. Такую взаимосвязь, очевидно, понимал и Народно-революционный трибунал в Камбодже, выносивший приговор по преступлениям, совершенным красными кхмерами в этой стране в 70-е гг. XX в. Виновные были осуждены за совершение геноцида, к которому были отнесены также действия по запрещению вероисповедания, разрушению экономических и культурных структур [2, с. 34]. Как мы видим, камбоджийский трибунал расширил понимание геноцида по сравнению с его пониманием в Конвенции 1948 г., усмотрев возможность ликвидации группы, в том числе путем разрушения ее культурно-экономических основ.

Таким образом, опираясь на приведенные исторические факты, можно заключить, что уничтожение культуры человеческой группы лишает ее проявлений собственной идентичности и может привести к ее исчезновению. В связи с этим опасность культурного геноцида видится не меньшей, чем опасность действий, предусмотренных действующей редакцией ст. 357 УК РФ и направленных на уничтожение человеческих общностей. В обоих случаях действия способны привести к ликвидации группы, обладающей собственной уникальной идентичностью, и в результате к сокращению разнообразия всего человечества. Следовательно, концепцию криминализации культурного геноцида стоит поддержать.

Среди видных сторонников рассматриваемой концепции нужно назвать А.Н. Трайнина. На основе анализа преступлений германского нацизма среди форм геноцида он выделял и на- ционально-культурный, который отличался направленностью на уничтожение национальной культуры преследуемых народов, их достижений и богатств [26, с. 222]. Среди иных форм геноцида, выделяемых автором, присутствуют «физический - непосредственное физическое истребление людей, принадлежащих к определенной расе или нации; биологический - борьба с рождением новых членов гонимой нации или расы (борьба с деторождением, стерилизация, запрещение браков, полное разделение полов, принудительные аборты, если зачатие произошло)» [27, с. 847-848]. Стоит отметить, что данная классификация носила скорее теоретический характер, так как ее автором отмечалось отсутствие проявлений национально-культурного геноцида среди действий, составляющих это преступление согласно Конвенции 1948 г. Данный факт, однако, исследователем критиковался и относился к недостаткам международно-правового акта.

Обращаясь к приведенной классификации форм геноцида А.Н. Трайнина уже применительно к норме, предусматривающей ответственность за это преступление в российском уголовном законе, современные исследователи полагают, что ст. 357 УК РФ закрепляет ответственность лишь за физическое и биологическое уничтожение групп [28, с. 93]. Однако это не так. В частности, причинение тяжкого вреда здоровью членам группы при совершении геноцида не связано с физическим истреблением людей и не направлено на недопущение рождения новых членов группы. Отмеченное справедливо и для принудительной передачи детей из одной человеческой группы в другую. Таким образом, названные действия, закрепленные в ст. 357 УК РФ, не укладываются в приведенную классификацию, не имевшую в основе нормативного определения этого преступления.

Мы предлагаем иную, лишенную указанного недостатка классификацию действий, образующих геноцид. В ее основу положена направленность совершаемых действий. К первой группе следует отнести такие признаки объективной стороны, как убийство и создание жизненных условий, рассчитанных на физическое уничтожение членов группы. Эти действия направлены на причинение смерти членам человеческих групп и в результате на физическое уничтожение самих общностей людей. Ко второй группе относятся действия, имеющие целью фактическое прекращение существования группы без физического уничтожения ее членов. Десоциализация (в зарубежной литера- 
туре это явление зачастую называют «социальной смертью» [29, р. 10]) членов группы в случае причинения тяжкого вреда здоровью, препятствование воспроизводству группы в случае с принудительной передачей детей и воспрепятствованием деторождению выступают факторами, способными привести к исчезновению группы, не причинив смерти ни одному ее члену. Разумеется, действия как первой, так и второй группы, хотя они объективно и направлены на ликвидацию человеческих групп, могут рассматриваться в качестве геноцида только при наличии цели полного или частичного уничтожения национальной, этнической, расовой или религиозной группы, указанной в диспозиции ст. 357 УК РФ.

В науке выдвинуто предположение, что под признак «предумышленного создания для группы таких жизненных условий, которые рассчитаны на полное или частичное физическое ее уничтожение» в Конвенции 1948 г. и соответствующий ему признак «создания жизненных условий, рассчитанных на физическое уничтожение членов группы» в ст. 357 УК РФ могут подпадать и экономические, политические и другие культурные условия [18]. Однако, как видно из приведенной выше классификации, данная точка зрения неверна. Это деяние предполагает направленность на причинение смерти членам группы и относится к геноциду, нацеленному на физическое уничтожение общностей людей. Культурный геноцид, в случае его нормативного закрепления, относился бы ко второй группе, так как был бы направлен на фактическое уничтожение человеческой группы путем лишения ее отличительных особенностей, собственной идентичности и, как результат, исчезновение самой группы. Следовательно, культурный геноцид, в сущности, не противоречит концепции геноцида, нашедшей нормативное закрепление.

Разделяя позицию о необходимости расширения понятия геноцида за счет включения в него действий по уничтожению культурных основ существования человеческих групп, мы предлагаем следующее решение. Диспозиция ст. 357 УК РФ содержит признак «создание жизненных условий, рассчитанных на физическое уничтожение членов группы». Из формулировки данного признака следует, что законодатель не предусмотрел в ст. 357 УК РФ возможность создания жизненных условий, рассчитанных на фактическое уничтожение группы без физического истребления ее членов. Как следует из приведенной классификации, такое уничтожение также ставит под угрозу безопасность национальной, этнической, расовой или религиозной группы основной непосредственный объект геноцида [30]. В существующем изложении признак «создание жизненных условий» предполагает открытый перечень действий, направленных на физическое уничтожение членов национальной, этнической, расовой или религиозной группы [31]. Список действий, перечисленных в действующей редакции ст. 357 УК РФ и направленных на фактическое уничтожение охраняемых групп, является закрытым. Следовательно, безопасность национальной, этнической, расовой или религиозной группы не охраняется от посягательств, не указанных в ст. 357 УК РФ. Этот недостаток может быть устранен путем исключения термина «физическое» из формулировки анализируемого признака. Такое законодательное решение автоматически включит в понятие геноцида, наряду с физическим уничтожением групп, все действия, направленные на уничтожение культурных основ существования группы, ликвидацию ее идентичности и в результате фактическое исчезновение самой группы. Таким образом, отечественным законодателем может быть воспринята концепция культурного геноцида, поддерживаемая многими исследователями со времени разработки Конвенции 1948 г.

\section{СПИСОК ИСПОЛЬЗОВАННОЙ ЛИТЕРАТУРЫ}

1. Шулепов Н.А. Имплементация норм международного права о геноциде в уголовном законодательстве зарубежных стран [Электронный ресурс] / Н.А. Шулепов // Российский военно-правовой сборник. - 2006. - № 8. - Режим доступа : http://www.voenprav.ru/doc-4311-4.htm.

2. Международное уголовное право : учеб. пособие / И.П. Блищенко [и др.] ; под общ. ред. В.Н. Кудрявцева. - М. : Наука, 1999. - 264 с.

3. Szpak A. National, Ethnic, Racial, and Religious Groups Protected against Genocide in the Jurisprudence of the ad hoc International Criminal Tribunals / A. Szpak // The European Journal of International Law. - 2012. - Vol. 23, № 1. - P. $155-173$.

4. Amann D.M. Group Mentality, Expressivism, and Genocide / D.M. Amann // International Criminal Law Review. - 2002. № 2. - P. 93-143.

5. Видус Д.Э. Вопрос о группах, охраняемых Конвенцией «О предупреждении преступления геноцида и наказании за него» и идентификации жертв геноцида / Д.Э. Видус // Международное право и международные организации. - 2012. № 3. - С. 16-27.

6. Скуратова А.Ю. Международные преступления: современные проблемы квалификации / А.Ю. Скуратова. - М. : Инфра-М, 2012. - 160 с. 
7. Aptel C. The intent to commit genocide in the case law of the International criminal tribunal for Rwanda / C. Aptel // Criminal Law Forum. - 2002. - № 13. - P. 273-291.

8. Климчук Я.А. Классификация и динамика методов раскулачивания крестьянства / Я.А. Климчук // Мир науки, культуры, образования. - 2007. - № 2. - С. 36-38.

9. Мошенская Н.В. Геноцид - историческая и правовая характеристика понятия / Н.В. Мошенская // Адвокатская практика. - 2005. - № 3. - С. 30-35.

10. Мартиросян А.С. Геноцид в решениях современных международных трибуналов : дис. ... канд. юрид. наук : 12.00.08 / А.С. Мартиросян. - Ставрополь, 2014. - 166 с.

11. Арутюнян М.А. Понятие преступления геноцида. Историческая обусловленность международно-правового закрепления геноцида как преступления против безопасности человечества / М.А. Арутюнян // Адвокатская практика. 2009. - № 4. - С. 38-41.

12. Хлебушкин А. Установление признаков социальной группы при квалификации преступлений экстремистской направленности: теория и судебная практика / А. Хлебушкин // Уголовное право. - 2013. - № 6. - С. 74-81.

13. Шхагапсоев 3.Л. Дефиниция социальной группы в преступлениях экстремистской направленности / 3.Л. Шхагапсоев // Общество и право. - 2011. - № 5. - С. 147-154.

14. Панкратова Е.Д. К вопросу об определении объекта геноцида / Е.Д. Панкратова // Пробелы в российском законодательстве. - 2010. - № 2. - С. 214-215.

15. Bauer Y. Genocide Prevention in Historical Perspective / Y. Bauer // Politorbis. - 2009. - № 47. - P. 25-32.

16. Аванесян В.В. Геноцид: криминологическое исследование : дис. ... канд. юрид. наук : 12.00 .08 / В.В. Аванесян. M., 2010. -235 c.

17. Macleod C. An Alternative Approach to the Harm of Genocide / C. Macleod // Politics. - 2012. - Vol. 32 (3). - P. 197-206.

18. Бем М.В. Эволюция концепции геноцида Р. Лемкина / М.В. Бем // Российский юридический журнал. - 2013. № 6. - С. 36-41.

19. Балашов Л.Е. Философия : учебник / Л.Е. Балашов. - М. : Дашков и Кㅜ, 2005. - 672 с.

20. Lemkin R. Genocide - A Modern Crime / R. Lemkin // Free World. - 1945. - Vol. 4. - P. 39-43.

21. Lemkin R. Axis Rule in Occupied Europe: Laws of Occupation - Analysis of Government - Proposals for Redress / R. Lemkin. - New Jersey : The Lawbook Exchange Itd, 2005. - 674 p.

22. Князькина А.К. Проблемы имплементации конвенционных норм о геноциде в УК РФ / А.К. Князькина // Российский следователь. - 2012. - № 23. - С. 40-41.

23. Клебанов Л.Р. Уголовно-правовая охрана культурного суверенитета России / Л.Р. Клебанов // Уголовное право. 2008. - № 5. - С. 28-34.

24. Морозов С.Д. Мужчины, женщины и дети на оккупированных территориях СССР в годы Великой Отечественной войны: численность и потери / С.Д. Морозов // Женщина в российском обществе. - 2015. - № 2 (75). - С. 37-48.

25. Краус Т. Венгерские войска и нацистская истребительная политика на территории Советского Союза / Т. Краус, Е.М. Варга // Журнал российских и восточноевропейских исторических исследований. - 2015. - № 1 (6). - С. 73-96.

26. Трайнин А.Н. Защита мира и борьба с преступлениями против человечества / А.Н. Трайнин ; отв. ред. Б.С. Никифоров. - М. : Изд-во Акад. наук СССР, 1956. - 299 с.

27. Трайнин А.Н. Избранные труды / А.Н. Трайнин ; сост., вступ. ст. Н.Ф. Кузнецовой. - СПб. : Юрид. центр Пресс, 2004. -898 с.

28. Кибальник А.Г. Преступления против мира и безопасности человечества / А.Г. Кибальник, И.Г. Соломоненко ; под науч. ред. А.В. Наумова. - СПб. : Юрид. центр Пресс, 2004. - 385 с.

29. Schott R.M. War rape, natality and genocide / R.M. Schott // Journal of Genocide Research. - 2011. - Vol. 13. - P. 5-21.

30. Москалев Г.Л. Объект преступления, предусмотренного ст. 357 УК РФ (геноцид) / Г.Л. Москалев // Вестник Пермского университета. - 2013. - № 2. - С. 237-243.

31. Москалев Г.Л. Создание условий, рассчитанных на физическое уничтожение национальной, расовой, этнической или религиозной группы, как способ совершения геноцида / Г.Л. Москалев // Известия Юго-Западного государственного университета. Сер. : История и право. - 2013. - № 1. - С. 83-90.

\section{REFERENCES}

1. Shulepov N.A. Implementation of international law norms on genocide in the criminal legislation of foreign countries. Rossiiskii voenno-pravovoi sbornik = Russian Military Law Collection, 2006, no. 8. Available at: http://www.voenprav.ru/doc-4311-4. htm. (In Russian).

2. Blishchenko I.P. et al.; Kudryavtsev V.N. (ed.). Mezhdunarodnoe ugolovnoe pravo [International Criminal Law]. Moscow, Nauka Publ., 1999. 264 p.

3. Szpak A. National, Ethnic, Racial, and Religious Groups Protected against Genocide in the Jurisprudence of the ad hoc International Criminal Tribunals. The European Journal of International Law, 2012, vol. 23, no. 1, pp. 155-173.

4. Amann D.M. Group Mentality, Expressivism, and Genocide. International Criminal Law Review, 2002, no. 2, pp. 93-143.

5. Vidus D.E. The issue of groups protected by the Convention for the Prevention and Punishment of the Crime of Genocide and the identification of genocide victims. Mezhdunarodnoe pravo i mezhdunarodnye organizatsii = International Law and International Organizations, 2012, no. 3, pp. 16-27. (In Russian).

6. Skuratova A.Yu. Mezhdunarodnye prestupleniya: sovremennye problemy kvalifikatsii [International Crimes: Contemporary Issues of Qualification]. Moscow, Infra-M Publ., 2012. 160 p.

7. Aptel C. The intent to commit genocide in the case law of the International criminal tribunal for Rwanda. Criminal Law Forum, 2002, no. 13, pp. 273-291.

8. Klimchuk Ya.A. The Classification and dynamics of peasants' dispossession methods. Mir nauki, kul'tury, obrazovaniya = The World of Science, Culture, Education, 2007, no. 2, pp. 36-38. (In Russian).

Russian Journal of Criminology, 2016, vol. 10, no. 3, pp. 511-520 
9. Moshenskaya N.V. Genocide - the historical and legal characteristic of the concept. Advokatskaya praktika = Advocate's Practice, 2005, no. 3, pp. 30-35. (In Russian).

10. Martirosyan A.S. Genotsid v resheniyakh sovremennykh mezhdunarodnykh tribunalov. Kand. Diss. [Genocide in the decisions of contemporary international tribunals. Cand. Diss.]. Stavropol, 2014. 166 p.

11. Arutyunyan M.A. The concept of the crime of genocide. Historical conditioning of including genocide in international law as a crime against the safety of the humanity. Advokatskaya praktika=Advocate's Practice, 2009, no. 4, pp. 38-41. (In Russian).

12. Khlebushkin A. Establishing the features of a social group in classification of extremist crimes: theory and judicial practice. Ugolovnoe pravo = Criminal law, 2013, no. 6, pp. 74-81. (In Russian).

13. Shkhagapsoev Z.L. The definition of a social group in the crimes of extremism. Obshchestvo $i$ pravo = Society and law, 2011, no. 5, pp. 147-154. (In Russian).

14. Pankratova E.D. To the issue of determining the object of genocide. Probely $v$ rossiyskom zakonodatel'stve $=$ Lacks in Russian legislation, 2010, no. 2, pp. 214-215. (In Russian).

15. Bauer Y. Genocide Prevention in Historical Perspective. Politorbis, 2009, no. 47, pp. 25-32.

16. Avanesyan V.V. Genotsid: kriminologicheskoe issledovanie. Kand. Diss. [Genocide: a criminological study. Cand. Diss.]. Moscow, 2010. 235 p.

17. Macleod C. An Alternative Approach to the Harm of Genocide. Politics, 2012, vol. 32 (3), pp. 197-206.

18. Bem M.V. Evolution of R. Lemkin's concept of genocide. Rossiiskii yuridicheskii zhurnal = Russian Law Journal, 2013, no. 6, pp. 36-41. (In Russian).

19. Balashov L.E. Filosofiya [Philosophy]. Moscow, Dashkov i K Publ., 2005. 672 p.

20. Lemkin R. Genocide - A Modern Crime. Free World, 1945, vol. 4, pp. 39-43.

21. Lemkin R. Axis Rule in Occupied Europe: Laws of Occupation - Analysis of Government - Proposals for Redress. New Jersey, The Lawbook Exchange Itd, 2005. $674 \mathrm{p}$.

22. Knyaz'kina A.K. The issues of implementing conventional norms on genocide in the CC of the RF. Rossiiskii sledovatel' = Russian Investigator, 2012, no. 23, pp. 40-41. (In Russian).

23. Klebanov L.R. Criminal law protection of cultural sovereignty of Russia. Ugolovnoe pravo $=$ Criminal law, 2008, no. 5, pp. 28-34. (In Russian).

24. Morozov S.D. Men, women and children on occupied territories of the USSR during the Great Patriotic War: the population size and losses. Zhenshchina $v$ rossiiskom obshchestve = Woman in Russian Society, 2015, no. 2 (75), pp. 37-48. (In Russian).

25. Kraus T., Varga E.M. Hungarian troops and Nazi extermination policy on the territory of the Soviet Union. Zhurnal rossiiskikh $i$ vostochnoevropeiskikh istoricheskikh issledovanii = The Journal of Russian and Eastern European Historical Research, 2015, no. 1 (6), pp. 73-96. (In Russian).

26. Trainin A.N.; Nikiforov B.S. (ed.). Zashchita mira i bor'ba s prestupleniyami protiv chelovechestva [The Protection of Peace and the Counteraction to Crimes against Humanity]. Moscow, Academy of Sciences of the USSR Publ., 1956. 299 p.

27. Trainin A.N.; Kuznetsova N.F. (ed.). Izbrannye Trudy [Selected Research Papers]. Saint Petersburg, Yuridicheskii tsentr Press, 2004. $898 \mathrm{p}$

28. Kibal'nik A.G., Solomonenko I.G.; Naumov A.V. (ed.). Prestupleniya protiv mira i bezopasnosti chelovechestva [Crimes against Peace and the Safety of the Humanity]. Saint Petersburg, Yuridicheskii tsentr Press, 2004. 385 p.

29. Schott R.M. War rape, natality and genocide. Journal of Genocide Research, 2011, vol. 13, pp. 5-21.

30. Moskalev G.L. The object of a crime provided by the Article 357 of the Criminal Code of Russian Federation (genocide). Vestnik Permskogo universiteta $=$ Bulletin of Perm State University, 2013, no. 2, pp. 237-243. (In Russian).

31. Moskalev G.L. An infliction on the gruop conditions of life calculated to bring about its physical destruction in whole or in part as a method of commitment of a crime of genocide. Izvestiya Yugo-Zapadnogo gosudarstvennogo universiteta = Bulletin of Southwest State University, 2013, no. 1, pp. 83-90. (In Russian).

\section{ИНФОРМАЦИЯ ОБ АВТОРАХ}

Тарбагаев Алексей Николаевич - заведующий кафедрой уголовного права Юридического института Сибирского федерального университета, доктор юридических наук, профессор, заслуженный юрист Российской Федерации, г. Красноярск, Российская Федерация; e-mail: alex_t@4mail.ru.

Москалев Георгий Леонидович - старший преподаватель кафедры уголовного права Юридического института Сибирского федерального университета, г. Красноярск, Российская Федерация; e-mail: eucaliptus@yandex.ru.

\section{БИБЛИОГРАФИЧЕСКОЕ ОПИСАНИЕ СТАТЫИ}

Тарбагаев А.Н. Основные направления совершенствования нормы об уголовной ответственности за геноцид в УК РФ / А.Н. Тарбагаев, Г.Л. Москалев // Всероссийский криминологический журнал. - 2016. T. 10, № 3. - C. 511-520. - DOI : 10.17150/19967756.2016.10(3).511-520.

\section{INFORMATION ABOUT THE AUTHORS}

Tarbagaev, Aleksey N. - Head, Chair of Criminal Law, Law Institute, Siberian Federal University, Doctor of Law, Professor, Honored Lawyer of the Russian Federation, Krasnoyarsk, the Russian Federation; e-mail: alex_t@4mail.ru.

Moskalev, Georgii L. - Senior Lecturer, Chair of Criminal Law, Law Institute, Siberian Federal University, Krasnoyarsk, the Russian Federation; e-mail: eucaliptus@yandex.ru.

\section{BIBLIOGRAPHIC DESCRIPTION}

Tarbagaev A.N., Moskalev G.L. Key directions for modernizing the norm on criminal liability for genocide in the Criminal Code of the Russian Federation. Vserossiiskii kriminologicheskii zhurnal = Russian Journal of Criminology, 2016, vol. 10, no. 3, pp. 511-520. DOI: 10.17150/19967756.2016.10(3).511-520. (In Russian). 